Revista Universo Contábil, ISSN 1809-3337

FURB, v. 6, n.1, p. 06-27, jan./mar., 2010

doi:10.4270/ruc.2010101

Disponível em www.furb.br/universocontabil

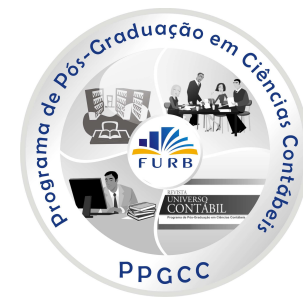

\title{
ANÁLISE DA REGULAÇÃO DA CONTABILIDADE À LUZ DA TEORIA TRIDIMENSIONAL DO DIREITO DE MIGUEL REALE*
}

\section{AN ACCOUNTING REGULATION ANALYSIS THROUGH THE LENS OF MIGUEL REALE'S TRIDIMENSIONAL THEORY OF LAW}

Ricardo Lopes Cardoso

Professor da EBAPE/FGV

Professor da FAF/UERJ

Endereço: Praia de Botafogo, 190, sala 501, Botafogo

CEP: 22250-090 - Rio de Janeiro/RJ - Brasil

E-mail: ricardo.lopes.cardoso@fgv.br Telefone: (21) 3799-5781

Marcelo Adriano Silva

Mestre em Administração pela EBAPE/FGV Endereço: Praia de Botafogo, 190, sala 501, Botafogo CEP: 22250-090 - Rio de Janeiro/RJ - Brasil

E-mail: madrianosil@uol.com.br Telefone: (21) 3799-5781

Poveri do Carmo Mário Professor do Mestrado em Ciências Contábeis da UFMG Endereço: Avenida Antônio Carlos, 6627 - Pampulha CEP: 31270-901 - Belo Horizonte/MG - Brasil

E-mail: poueri@gmail.com

Telefone: (31) 3409-7267

Sérgio de ludícibus

Professor do Mestrado em Ciências Contábeis e Financeiras da Pontifícia Universidade Católica de São Paulo - PUC/SP Professor Titular Aposentado e Emérito da Universidade de São Paulo Endereço: Avenida Professor Luciano Gualberto, 908, Cidade Universitária CEP: 05508-900 - São Paulo/SP - Brasil E-mail: siudicibus@uol.com.br

Telefone: (11) 3091-5820

\footnotetext{
Artigo recebido em 06.03.2009. Revisado por pares em 24.04.2009. Reformulado em 02.07.2009. Recomendado em 08.07.2009 por Ilse Maria Beuren (Editora). Publicado em 02.02.2010. Organização responsável pelo periódico: FURB.
} 


\section{RESUMO}

Um dos grandes desafios da comunidade contábil (reguladores, acadêmicos, elaboradores e auditores das demonstrações contábeis) diz respeito à escolha de padrões contábeis capazes de definir a forma mais adequada para o reconhecimento, mensuração e divulgação das informações econômico-financeiras ao público externo. Nessa situação, a regulação da contabilidade exerce importante papel na conduta técnica de profissionais da área e no desenvolvimento de práticas que atendam os anseios dos usuários no tocante à quantidade $\mathrm{e}$ qualidade das informações contábeis. No que tange ao Brasil, esse é o principal motivo das profundas alterações pelas quais vem passando o conjunto regulatório da contabilidade societária. Tais alterações envolvem: a criação do Comitê de Pronunciamentos Contábeis (CPC), a edição das Leis $\mathrm{n}^{\circ} 11.638 / 07$ e 11.941/09 e a recente edição de uma série de deliberações pela Comissão de Valores Mobiliários (CVM). Este artigo se propõe, enquanto ensaio teórico e numa perspectiva interdisciplinar, a utilizar a Teoria Tridimensional do Direito, elaborada por Miguel Reale, para o entendimento e o debate da regulação da contabilidade financeira. Segundo Reale, a norma jurídica decorre do diálogo entre fato, valor e norma, mediante a intervenção de um ente dotado de poder. Os fatos econômico-financeiros que afetam as entidades são interpretados por um ente dotado de poder (CPC, por exemplo) segundo os valores compartilhados pela sociedade (compreensibilidade, relevância, confiabilidade e comparabilidade, por exemplo) e daí surgem as normas (padrões contábeis).

Palavras-chave: Regulação. Teoria Tridimensional. Fato. Norma. Valor.

\section{ABSTRACT}

One of the most relevant challenges that accounting community (regulators, academics, prepares $e$ auditors of financial reports) faces nowadays is regarding the design of accounting standards, in order to provide a faithful representation of a company's economic and financial position to stakeholders. In this context, accounting regulation is crucial on professionals' skills improvement and on shaping accounting practices to meet the stakeholders expectations related to the quantity and the quality of the accounting information. This is the most relevant reason for the actual process of changes on the Brazilian Financial Reporting Standards. Those changes include: the creation of Comitê de Pronunciamentos Contábeis (CPC, the Brazilian Financial Accounting Standards Board), the edition of the Laws $n^{\circ} 11.638 / 07$ and 11.941/09, and of a set of accounting standards by the Comissão de Valores Mobiliários (CVM, the Brazilian Securities \& Exchange Commission). While an interdisciplinary theoretical proposition, this paper suggests that Miguel Reale's Tridimensional Theory of Law is helpful in understanding the financial accounting regulation process. According to Reale, the rule (law) is a consequence of the dialectic relationship among fact, value and rule, through the intervention of an entity with authority (power). Financial and economic fact (and events) that affect a company's performance are analyzed by an entity with authority (CPC for instance) based on the values shared by the society (e.g., comprehensiveness, relevance, confidence, comparability), and from there rules (accounting standards) are developed.

Keywords: Regulation. Tridimensional Theory. Fact. Rule. Value. 


\section{INTRODUÇÃO}

Morin (2003) afirma que, cada vez mais, as disciplinas se fecham e não se comunicam umas com as outras e os fenômenos são fragmentados e não se consegue conceber a sua unidade, na qual a disciplina torna-se um meio de flagelar aquele que se aventura no domínio das idéias, que o especialista considera de sua propriedade. Assim, o estabelecimento da interdisciplinaridade visa romper o isolamento entre áreas, por meio da articulação de conceitos e esquemas cognitivos em um processo de enriquecimento mútuo. Segundo Andrade (1998, p. 93), "a interdisciplinaridade refere-se a uma nova concepção de ensino e currículo, baseada na interdependência entre os diversos ramos do conhecimento". Conforme Roslender e Dillard (2003), a abordagem interdisciplinar da contabilidade não é nova, entretanto, essa interdisciplinaridade vem sendo mais desenvolvida com os campos da estatística e da economia (inclusive da econometria) e das finanças.

Nesse sentido, este ensaio de natureza interdisciplinar busca contribuir com as pesquisas relacionadas ao fenômeno da regulação da contabilidade, motivado pelas inquietações manifestadas por Mattessich (1995), Hopwood (2007) e Laughlin (2007), sendo apresentada a Teoria Tridimensional do Direito, de Miguel Reale, como perspectiva de análise. Como ensaio teórico, a pesquisa bibliográfica buscou trazer o conversar e o pensar de autores para uma dialética, analisada pela Teoria Tridimensional, em que seus achados podem ser vistos como analíticos, providos de um processo dedutivo.

Além disso, o estudo é interdisciplinar pela circulação de conceitos, de esquemas cognitivos e de novas hipóteses explicativas; ou seja, pela constituição de concepções organizadoras que permitam articular os domínios disciplinares em um sistema teórico comum. Acredita-se que esta possa ajudar a esclarecer, de forma dedutiva, antigos problemas e situar novas questões envolvendo a legitimidade, a qualidade, os efeitos e a pertinência ou necessidade das normas contábeis em relação à realidade vivida pela sociedade em dado momento histórico. Portanto, a contribuição desta teoria consiste, essencialmente, em perceber que os três elementos - fato, valor e norma - possuem natureza funcional e dialética e estão sempre presentes e correlacionados em qualquer expressão da vida cultural, dedução primordial da teoria utilizada.

A regulação, como um processo que consiste na restrição intencional da escolha de atividades de um sujeito e proveniente de uma entidade reguladora, é um fenômeno inerente ao homem enquanto ser social. Assim, é uma decisão social, que deve ser aceita pelas partes, de maneira forçada e/ou voluntária (HORNGREN apud BELKAOUI, 2005, p. 10). O desejo de segurança e objetividade da informação gerada pela contabilidade financeira é refletido na adoção de padrões contábeis, que definem a forma de mensuração e de divulgação das informações econômico-financeiras para o público externo. Com isso, os princípios e as normas contábeis pretendem representar, então, a essência das doutrinas e teorias relativas à Ciência da Contabilidade, delimitando como a profissão irá se posicionar diante da realidade social, econômica e cultural que se apresenta.

No fundo, a regulação contábil é uma espécie de intervenção da sociedade, representada por comitês por ela criados. Isso, para não deixar totalmente ao livre arbítrio de cada contador e de cada entidade a escolha dos princípios e práticas subjacentes à elaboração das demonstrações contábeis, visto que essas atendem a milhares e até milhões de interessados nas informações contábeis. Mais do que atingir cumes de perfeição e avanço científico, a regulação objetiva elevar a qualidade média das normas a fim de contribuir para o aperfeiçoamento das qualidades das informações contábeis. Quando essa regulação é levada ao nível internacional, à convergência, cria soluções, mas também desafios. Veja, a esse respeito, Iudícibus (2007b). 
Spacek apud Bray (1966, p. 32) mencionam que:

Depois dos propósitos e objetivos de Contabilidade serem definidos corretamente, o próximo passo deve ser o estabelecimento de uma fundamentação básica para realizar estes propósitos e objetivos [...]. Então, princípios de Contabilidade são consistentes com aquela fundamentação que deveria ser determinada.

A necessidade de se fixar um conjunto de normas aceitas pelos profissionais contábeis e usuários da informação contábil, servindo como referência para preparação e divulgação das demonstrações contábeis, passa a ser o grande desafio de todos os envolvidos no processo de regulação da contabilidade. Conforme Iudícibus (2007a, p.45), “Apesar das diferenças de abordagens das várias escolas, devemos reconhecer que somente existe uma contabilidade, baseada em postulados, princípios, normas e procedimentos racionalmente deduzidos e testados pelo desafio da praticabilidade".

Todavia, vale destacar que a regulação, sob a ótica da informação contábil, por não alcançar todas as situações possíveis, pode estabelecer pontos de tensão entre o desejo dos entes reguladores e a necessidade dos entes regulados. Afinal, segundo Foroughi e Reed (1987, p. 70), "a contabilidade é um ramo de conhecimento humano que utiliza princípios e práticas universalmente compreendidos e geralmente aceitos".

Considerando, então, que as diretrizes e os padrões assumidos em função dos objetivos definidos pela contabilidade estão inseridos em múltiplos contextos políticos, econômicos, sociais e culturais, dos quais participam provedores e usuários das informações contábeis, pode-se assumir que o processo de regulação da contabilidade sofre, de certa maneira, influências e tendências diversas. Tal concepção é fortalecida pelo fato de a contabilidade resultar da convergência de fenômenos de ordem econômica, política, social, cultural etc. (DIAS FILHO; MACHADO, 2004, p. 54).

É possível compreender que nesse processo de integração normativa (regulação da contabilidade) de fatos (eventos essencialmente econômicos), estão inseridos valores inerentes à realidade histórica do homem, ou seja, a um determinado objeto ou evento econômico. Na realidade, são escolhidos valores capazes de indicar como ele deve ser, por meio de normas, para integrá-lo na qualidade de informação a uma nova realidade cultural, a contábil.

O artigo está organizado em seções, apresentando na seqüência breves comentários sobre a informação contábil e suas características qualitativas. Na seção 3 é abordado o processo de regulação da informação contábil. Na quarta seção, é resgatado o debate sobre a Teoria Normativa da Contabilidade. Na seção subseqüente, é apresentada a vinculação entre as normas contábeis e a estrutura conceitual básica da contabilidade, numa perspectiva histórica. A sexta seção é dedicada à apresentação dos fundamentos da Teoria Tridimensional do Direito, de Miguel Reale. Na sétima seção, o ensaio é apresentado, isto é, a proposta de se analisar a regulação da contabilidade à luz da Teoria Tridimensional do Direito. Finalmente, as considerações finais são apresentadas na oitava seção.

\section{INFORMAÇÃO CONTÁBIL}

Existem diferentes abordagens teóricas que procuram explicar o papel exercido pelo conhecimento contábil no estudo do patrimônio das entidades e na apreensão e análise das causas de suas mutações, visando o fornecimento de informações sobre seus aspectos de natureza econômica, financeira e física à sociedade. Nesse sentido Iudícibus, Martins e Gelbcke (2007, p 29), definem que "a contabilidade é, objetivamente, um sistema de informação e avaliação destinado a prover seus usuários com demonstrações e análises de 
natureza econômica, financeira, física e de produtividade, com relação à entidade objeto de contabilização".

A informação contábil, entendida como o mais amplo conjunto de informações, cujo processo de elaboração utiliza o arcabouço contábil (teoria, técnicas, princípios etc.) (CARDOSO, 2007, p. 149), segundo a já revogada, Resolução $n^{0} 785 / 95$ do Conselho Federal de Contabilidade (CFC), deve ser, em geral e antes de tudo, veraz e eqüitativa, de forma a satisfazer as necessidades comuns a um grande número de diferentes usuários. O mesmo poderia ser dito quanto à já revogada Deliberação CVM n 29/86, ou quanto a Resolução CFC $n^{\circ} 1.121 / 08$ ou Deliberação CVM n ${ }^{\circ}$ 539/08.

No entanto, Reale (1996a), ao criticar a noção de valor ideal, por seu caráter genérico e abstrato, propõe que o valor deva ser objetivado na norma. Ou seja, reconhece a necessidade de serem especificados atributos capazes de definir o valor visado, como, no caso, a veracidade e eqüidade da informação contábil pelo CFC. Sendo assim, como objetivo essencial da contabilidade, a informação reveste-se dos seguintes atributos considerados indispensáveis pela norma:

a) a confiabilidade (veracidade, completeza e pertinência do seu conteúdo; elemento essencial na relação usuário versus própria informação);

b) a tempestividade (a informação precisa chegar ao conhecimento do usuário em tempo hábil para sua utilização);

c) a compreensibilidade (clareza e objetividade da informação contábil divulgada);

d) a comparabilidade (possibilita ao usuário o conhecimento da evolução da informação, de forma a identificar suas posições relativas).

De forma semelhante à Resolução CFC $\mathrm{n}^{\circ}$ 785/95, o Pronunciamento Conceitual Básico, emitido pelo CPC e referendado pela CVM mediante a Deliberação $5 n^{\circ}$ 39/08 e pelo CFC, mediante a Resolução $\mathrm{n}^{\circ} 1.121 / 08$, estabelece que para a informação contábil atenda as necessidades dos usuários deve ter quatro características qualitativas principais: compreensibilidade, relevância, confiabilidade e comparabilidade.

Portanto, os valores presentes nos atributos das informações devem orientar as normas ou padrões contábeis que visem a prover os usuários com demonstrações e análises do patrimônio e suas mutações de determinada entidade. Segundo Reale (1963, p. 97), "o fim é a veste racional do valor enquanto alvo da ação".

\section{A REGULAÇÃO DA CONTABILIDADE}

O conceito de Regulação pode ser abordado por diferentes áreas. No campo das ciências sociais aplicadas, a Regulação é considerada um "controle mantido durante certo tempo e focalizado, exercido por uma instituição pública sobre atividades que são valorizadas pela comunidade" como aponta Selznick (1971 apud BALDWIN e CAVE, 1999, p. 2). Também pode ser definida como uma das formas de ação do Estado, através do controle do comportamento de firmas e de indivíduos (VISCUSI; VERNON; HARRINGTON JR., 2000).

Abranches (1999, p.19) acrescenta ainda que "praticamente toda ação do Estado envolve regulação, embora existam campos de intervenção estatais integralmente dedicados à função regulatória". Nessa linha, a regulação da contabilidade assume importante papel, no atendimento das necessidades de informação por parte de seus usuários, ao nortear a forma de elaboração e divulgação das informações contábeis.

O sistema de regulação da contabilidade de um país é influenciado por diferentes agentes (órgãos do Estado, organizações profissionais, instituições vinculadas ao mercado 
financeiro e à academia contábil) que interagem entre si e agem sobre o próprio sistema, podendo ocorrer ainda com o processo de convergência de normas aos padrões internacionais de contabilidade. De acordo com seus objetivos e autoridade, esses agentes formulam leis, decretos, regulamentos, padrões e recomendações direcionados às entidades, estabelecendo as políticas contábeis (segundo a terminologia adotada por Reale: normas) a serem adotadas pelos entes regulados na mensuração e evidenciação de suas transações.

A Contabilidade, na qualidade de ciência social aplicada, se sobressai pelo papel que exerce no processo de fornecimento de informações econômico-financeiras para permitir decisões e julgamentos adequados por parte dos diversos usuários da informação contábil e garantir, dessa forma, a prestação de contas destas entidades para os múltiplos segmentos da sociedade. Todavia, a existência de diversos agentes econômicos com os quais as organizações se relacionam e cada qual com interesses econômicos específicos têm por consequiência uma diversidade de usos da informação contábil.

Considerando, então, que tais usuários possuem diferentes interesses, surgem questões relativas a quais e de que forma as informações deveriam ser produzidas e evidenciadas objetivando suprir às necessidades dos usuários. Desponta, assim, o processo da regulação da contabilidade no qual um determinado agente, com poder estabelecido, elabora padrões ou normas capazes de definir a maneira que as informações contábeis devem ser geradas e divulgadas, como também a quem elas se aplicam.

Portanto, o fenômeno da regulação não deve ser analisado isoladamente, ou seja, independente do ambiente cultural, sócio-econômico e histórico; podendo ser considerado, inclusive, como um produto de certa ordem social (CHANTIRI, 1995), daí a necessidade de se desenvolver estudos interdisciplinares para se compreender a regulação da contabilidade este ensaio visa a contribuir com suas análises críticas.

\section{TEORIA NORMATIVA DA CONTABILIDADE}

O arcabouço conceitual da Contabilidade no Brasil ainda é predominantemente normativo, em relação às características objetivas das demonstrações contábeis. Segundo Hendriksen e Van Breda (1999), tanto as teorias indutivas quanto as teorias dedutivas podem ser descritivas (positivas) ou prescritivas (normativas). Iudícibus (2007a) menciona que, em ciência, ambas são utilizadas, ou seja, a indução e a dedução podem ser vistas como raciocínios complementares. Nesse sentido, Martins (2005) sugere que a sinergia entre pesquisas normativas e positivas poderia (poderá) gerar um círculo virtuoso.

O processo de elaboração de normas ou padrões contábeis, também não é unificado, tendo em vista a existência de vários órgãos e entidades profissionais que definem as práticas contábeis a serem seguidas. Essa indefinição impõe sérias dificuldades na fixação de padrões de contabilidade não apenas no âmbito dos países, mas também no plano internacional tornando mais complexas as interpretações para os usuários no geral. Na atualidade, atuam no desenvolvimento de procedimentos e harmonização de normas contábeis: o International Accounting Standards Board (IASB), a International Federation of Accountants (IFAC), o International Organization of Securities Commissions (IOSCO) e o International Standards of Accounting and Reporting (ISAR), da UNCTAD/ONU. O IOSCO representa as Comissões de Valores Mobiliários em âmbito mundial e atua em conjunto com o IASB para a fixação de Normas Internacionais de Contabilidade a serem adotadas nas ofertas de títulos multinacionais. O Financial Accounting Standards Board (FASB), embora tenha seu campo de atuação formal restringido pelas fronteiras dos Estados Unidos, teve significativa influência nas práticas contábeis de grandes empresas não norteamericanas, e, atualmente, 
mantém extensa agenda de trabalho junto com o IASB no sentido de reduzir as diferenças entre os U.S. GAAP e os IFRS.

A necessidade de harmonização das normas contábeis também passou a fazer parte das preocupações dos múltiplos órgãos e entidades reguladoras, como a Secretaria da Receita Federal do Brasil (RFB), a CVM, o Instituto de Resseguros do Brasil (IRB), o Instituto dos Auditores Independentes do Brasil (IBRACON) e o CFC. Em conseqüência desta inquietação foi constituído o CPC, em outubro de 2005, através da Resolução CFC no 1.055 e reconhecido, indiretamente, pela Lei $n^{\circ} 11.638 / 07$, como o órgão competente para centralizar os esforços de convergência das práticas contábeis brasileiras às internacionais. A instalação do CPC representa, assim, a perspectiva de importantes avanços no caminho da atualização e da modernização de normas e preceitos contábeis, inovando o trato de questões regulamentares ao reunir representantes de entidades das áreas privada, da academia e do setor governamental na busca da almejada modernidade.

Segundo Lopes e Lima (2001), os princípios e as normas contábeis adotados passaram a refletir o desejo de segurança e objetividade da informação produzida pela contabilidade, influenciando diretamente muitas convenções e princípios adotados pela profissão contábil internacionalmente. Franco (1997, p. 190) distingue a definição de princípios e a fixação de normas, como segue:

O processo de identificação dos Princípios difere daquele de fixação de normas contábeis. Esta fixação decorre do juízo de doutrinadores e profissionais, que buscam, através desse processo, encontrar regras mais adequadas para a contabilização dos fatos, objetivando cumprir os fins informativos e orientadores da Contabilidade.

Cabe ressaltar que no Brasil há mais de uma fonte emissora de normas contábeis. Destacam-se, no caso, o CFC e a CVM, juntamente com o IBRACON, que passaram a se constituir nos pilares da estrutura contábil nacional. Até que o documento elaborado pelo IASB, com o título Framework for the Preparation and Presentation of Financial Statements, fosse traduzido pelo CPC e aprovado pela CVM (Deliberação $n^{\circ}$ 539/08) e demais órgãos normatizadores.

\section{NORMAS CONTÁBEIS E A ESTRUTURA CONCEITUAL DA CONTABILIDADE}

Há décadas os profissionais ligados à Contabilidade, bem como organismos públicos, insistem em encontrar um conjunto de normas, padrões ou procedimentos contábeis que atendam suas necessidades, a fim de contribuir com o desenvolvimento de suas funções, visando atender às expectativas dos usuários das informações financeiras.

Diversos organismos representativos da classe contábil e de pesquisadores se propuseram a atingir tal objetivo. A identificação dos princípios, padrões e normas aplicáveis à Contabilidade, a partir da década de 1960, teve sua base fundamental constituída pelos objetivos da Contabilidade, características da informação contábil, critérios de reconhecimento e mensuração dos elementos nas demonstrações financeiras, a qual foi denominada Estrutura Conceitual de Contabilidade Financeira.

Um documento produzido pela Associação Americana de Contabilidade em 1966, denominado A statement of basic accounting theory, é apontado por Hendriksen e Van Breda (1999, p. 79) como o primeiro dos novos pronunciamentos de teoria da contabilidade a orientar-se para o usuário. Nessa linha, para que fosse possível atender aos desejos dos usuários, foi apresentada uma lista dos objetivos presumidos pela contabilidade. Comentário 
semelhante é feito por Laughlin (2007, p. 277-278) com relação ao "Corporate Report" produzido pelo Accounting Standard Setting Committee (ASSC), do Reino Unido, em 1975.

De acordo com a literatura contábil, os objetivos da contabilidade precisam ter relação com aquilo que o usuário considera elementos relevantes para o seu processo decisório. Iudícibus, Martins e Gelbcke (2007) afirmam que para o alcance desses objetivos da contabilidade, dois pontos são destacados: a) as empresas precisam dar ênfase à evidenciação de todas as informações que permitem avaliar a sua situação patrimonial e das mutações e, que possibilitem inferências futuras; b) a contabilidade deve guiar-se pelos seus objetivos de bem informar, seguindo, se for necessário, a essência ao invés da forma.

No Brasil, a Estrutura Conceitual Básica de Contabilidade foi elaborada, originalmente, pelo Instituto Brasileiro de Pesquisas Contábeis, Atuariais e Financeiras (IPECAFI), a qual o IBRACON incorporou, em 22 de novembro de 1985, ao seu conjunto de pronunciamentos técnicos, sendo, finalmente, aprovada pela CVM, por intermédio da Deliberação CVM no 29, de 5 de fevereiro de 1986. Em 2007, o CPC, a CVM e o CFC apresentaram pronunciamento básico, mediante Audiência Pública, relativo à estrutura conceitual para a elaboração das Demonstrações Contábeis, no qual estabelece os conceitos que fundamentam a preparação e a apresentação de demonstrações contábeis destinadas aos usuários externos. Tal pronunciamento foi aprovado pelo CPC no início de 2008, ficando conhecido como Pronunciamento CPC-00. Este pronunciamento foi referendado pela CVM (Deliberação $\mathrm{n}^{\circ}$ 539/08), pelo CFC (Resolução $\mathrm{n}^{\circ}$ 1.121/08), pela Superintendência de Seguros Privados (Circular SUSEP n ${ }^{\circ}$ 379/08) e pela Agência Nacional de Energia Elétrica (Despacho ANEEL ${ }^{\circ}$ 4.796/08). Ao traduzir a Estrutura Básica elaborada pelo IASB, inaugura-se no Brasil uma nova postura de apresentação dos conceitos contábeis fundamentais.

A importância da estrutura conceitual é defendida por King (2006, p. 74), ao ressaltar que entre 1939 e 1959 o Committee on Accounting Procedure (CAP), uma divisão do AICPA, emitiu diversos pronunciamentos contábeis (bulletins) tratando de temas específicos da contabilidade, antes de se definir qual seria a estrutura conceitual básica da contabilidade (conceptual framework). Este fato foi duramente criticado pela Securities Exchange Committee (SEC) e membros da academia, demonstrando a necessária relação entre as normas e os valores que estão presentes nos princípios, pressupostos e características qualitativas da informação contábil.

$\mathrm{Na}$ teoria tridimensional de Reale (2005), o valor, como elemento de mediação dialética entre fato e norma, revela uma conexão ou um interesse, no plano normativo da realidade percebida, não considerada nas concepções unilaterais ou reducionistas que envolvem a estrutura conceitual da contabilidade. Concepções essas que, embora aceitem a existência de fato, norma e valor na experiência contábil, de certa maneira possivelmente privilegiem apenas um dos fatores em detrimento de outros, ocultando, assim, faces necessárias para uma compreensão integral do fenômeno contábil. Por exemplo, a teoria da competição entre grupos de interesse (BECKER, 1983; POSNER, 1971), na linha de Law \& Economics, foca quase que exclusivamente o valor ao demonstrar que os grupos de interesses (concorrentes entre si) exercem pressão sobre o regulador no sentido de que a norma seja elaborada de forma a atender seus objetivos. Embora o termo valor não seja adotado, é certo que os interesses de cada grupo são impregnados e definidos pelos respectivos valores. 


\title{
6 A TEORIA TRIDIMENSIONAL DO DIREITO
}

Em 1940, Miguel Reale começou a elaborar sua Teoria Tridimensional do Direito, numa reação contra o formalismo jurídico e o pensamento essencialmente analítico e reducionista que, então, era predominante à época.

\begin{abstract}
Direito não é só norma, como quer Kelsen, Direito não é só fato como rezam os Marxistas ou os economistas do Direito, porque Direito não é economia. Direito não é produção econômica, mas envolve a produção econômica e nela interfere; o Direito não é principalmente valor, como pensam os adeptos do Direito natural tomista, por exemplo, porque o Direito ao mesmo tempo é norma, é fato e é valor (REALE, 2005, p. 119).
\end{abstract}

De acordo com o pensamento tomista, o direito natural é um núcleo de princípios em que se devevem inspirar as fórmulas dos códigos positivos que. Segundo Canotilho (apud GARCÍA, 1999, p. 281), as concepções cristãs medievais, especialmente o direito natural tomista, ao distinguir entre lex divina, lex natura e lex positiva, abriram o caminho para a necessidade de submeter o direito positivo às normas jurídicas naturais, fundadas na própria natureza dos homens.

No ano de 1953, surgiu outro importante componente em sua teoria, a dialeticidade dos três elementos (fato, valor e norma), em que eles não simplesmente se correlacionam, mas dialogam. Reale, ao pensar nesse processo dialético que envolvia tais elementos, percebeu que há uma dinamicidade integrante e convergente entre esses três fatores, formando, então, a noção de estrutura tridimensional, cujo processo e demonstrado na Figura 1.

\begin{tabular}{|c|c|c|c|c|c|c|}
\hline $\left.1^{\circ}\right)$ & Fato & $\Longrightarrow$ & Valor & $\Longrightarrow$ & Norma & Ciência do Direito \\
\hline $\left.2^{\circ}\right)$ & Norma & 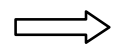 & Valor & 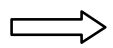 & Fato & Sociologiada do Direito \\
\hline $\left.3^{\circ}\right)$ & Fato & $\Longrightarrow$ & Norma & $\Longrightarrow$ & Valor & Filosofia do Direito \\
\hline
\end{tabular}

Figura 1 - Dinamicidade integrante e convergente

Fonte: Reale (2005, p. 121).

A Figura 1 evidencia uma distinção vetorial para cada campo de conhecimento jurídico, no qual a ciência do direito busca uma compreensão normativa dos fatos em função de valores, ou seja, o direito pode ir do fato ao valor, visando atingir a norma para interpretála e aplicá-la (exemplo: não é possível desconsiderar a norma constitucional, porém é possível atingi-la na contextualização dos acontecimentos e dos valores presentes na sociedade). Já a sociologia do direito tem uma compreensão factual das normas em função dos valores, quer dizer, o fato jurídico não se compreende sem referir-se a uma norma e ao valor que se visa realizar (exemplo: compreender a questão da propriedade intelectual sem orientação normativa e sem conhecer o valor envolvido nela é inconcebível). Finalmente, a filosofia do direito procura uma compreensão axiológica de fatos em função de normas, ou seja, o direito pode ir do fato à norma para chegar ao entendimento do valor como modalidade do justo (exemplo: entender a legitimidade do uso da força que se funda em razões de justiça). Ressalte-se que o termo axiologia designa a filosofia dos valores, fundada em Baden por W. Windelband (1863-1915).

O conceito de dialética é ampliado, no ano de 1968, por meio do desenvolvimento de uma concepção advinda da física, a dialética da complementaridade - o princípio de complementaridade foi apresentado pelo físico dinamarquês Niels Bohr, tendo por fim 
superar o conflito surgido na Física entre a teoria corpuscular e a teoria ondulatória da luz. Bohr (2000) propõe que os fenômenos no mundo subatômico surgiriam na forma de complexos (sínteses) da relação complementar entre os objetos subatômicos. Ela foi inserida na experiência jurídica, como modalidade histórico-cultural, na qual o valor atua como um dos elementos que constituem essa realidade, refletindo na compreensão da realidade por ele constituída e, também, como justificativa de conduta. Logo, o Direito não está disperso no espaço e no tempo, ao contrário, está imerso na vida humana.

Entretanto, vale ressaltar que a natureza tridimensional da experiência jurídica já era defendida por teóricos em outros países, como a Alemanha, Itália e França. O aspecto concreto e dinâmico, o qual diferencia a teoria tridimensional de Reale das demais, consiste na idéia que os três elementos (norma, fato e valor) estão sempre presentes e correlacionados em qualquer expressão da vida cultural de maneira funcional e dialética. Portanto, diante da tensão existente entre o fato, como elo de encadeamento dos atos humanos situados na história, e o valor do qual o homem é considerado a origem (valor-fonte), surge o momento normativo como solução superadora e integrante do tempo e do espaço.

No dinâmico processo de transformações que envolvem as relações sociais, os termos cultura, história e axiologia estão inter-relacionados num processo complementar e dialético. De maneira pragmática, Reale (2005) afirma que cultura pode ser definida como o acervo de bens objetivados pelo espírito humano na realização de seus fins específicos. O pensar e o agir são constantemente modificados e ampliados por nós e como toda ação humana consciente tem por objetivo alcançar determinados fins, esses mesmos fins são escolhidos pelo homem de acordo com os valores que ele considera importantes para a sua vida.

Ao longo da história, tanto as teorias quanto as explicações conceituais da realidade, do homem, da história, da filosofia etc. sofrem mudanças (KUHN, 1970). Logo, a relação da cultura com a história e axiologia é explicada pelo fato de a realidade humana ter sido projetada e concretizada através dos diferentes ciclos históricos, nos quais a cultura se desenvolve (GARCIA, 1999). Daí o termo historicismo axiológico incorporado por Reale na fundamentação de sua teoria.

Toda a realidade humana é cultural e se constitui graças às diferentes seleções que o homem realiza na história. As objetivações dessas seleções ou estimativas sobre a realidade transcendente constituem o mundo da cultura, que a partir do que foi previamente dito, só pode ser axiológico e impregnado de algum valor. (GARCIA, 1999, p. 46).

De acordo com Japiassu (2001, p. 129), o historicismo corresponde ao método filosófico que tenta explicar sistematicamente pela história, isto é, pelas circunstâncias da evolução das idéias e dos costumes ou pelas transformações das estruturas econômicas, todos os acontecimentos relevantes do direito, da moral, da religião e de todas as formas de progresso da consciência.

Considerando, então, a presença dos três elementos na vivência cotidiana (mundo da vida), surge na teoria Realeana uma importante correlação funcional envolvendo a vigência, que se refere à norma, a eficácia que se reporta ao fato e o fundamento que expressa a exigência de um valor (REALE, 1994). Logo, o processo axiológico-factual-normativo, que consiste nas alterações semânticas da norma pela superveniência de mudanças no plano dos fatos e valores e que pode culminar na sua revogação pressupõe uma tomada de posição normativa perante fatos sociais impregnados de valores.

Tal acepção somente é possível por meio da Dialética da Complementaridade, ao estabelecer uma ligação entre fatos e valores, na qual cada valor se atualiza em momentos existenciais diante das mudanças fáticas no nosso cotidiano, num processo dinâmico e 
complementar, conforme demonstrado na Figura 2, ou seja, da relação fático-axiológica (F1 e V1), nasce a norma (N1) que sofre alterações com a influência de novos fatos (Fn) e novos valores (Vn), adequando-se, assim, à nova realidade cultural.

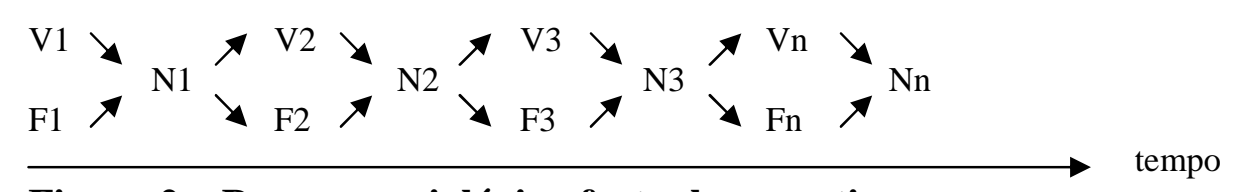

Figura 2 - Processo axiológico-factual-normativo

Fonte: adaptado de Reale (2005, p. 101).

Para ampliar este processo que envolve os três elementos (norma, fato e valor), como símbolo de expressão dialética, Reale (2005, p. 123) apresenta a nomogênese jurídica (Figura 3) que demonstra que o mundo jurídico é formado de contínuas "intenções de valor" (V1, V2, V3, V4), que incidem sobre uma "base de fato" (F), refletindo-se em várias direções normativas, se convertendo em norma jurídica em virtude da inferência de poder (P). A norma jurídica $(\mathbf{N})$, então, não pode surgir espontaneamente dos fatos e dos valores, pois ela não pode prescindir da apreciação da autoridade (quem define a oportunidade e conveniência da norma a ser consagrada).

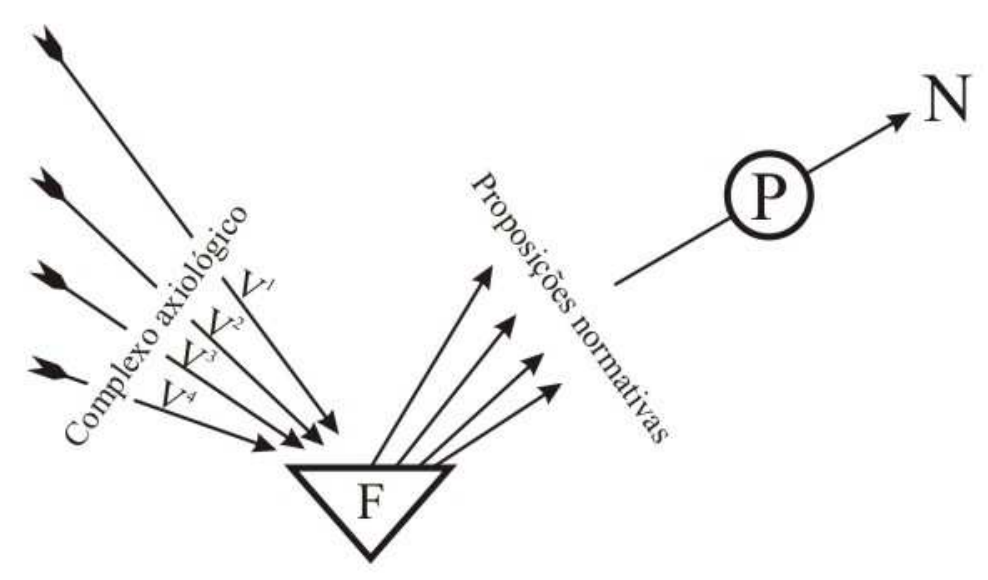

Nomogênese jurídica

Figura 3 - Nomogênese jurídica

Fonte: Reale (2005, p. 123).

A correlação dinâmica que envolve fato, valor e norma pode ser exemplificada através do processo normativo que abrangeu a correção monetária de balanço. O governo federal, com a edição da Lei $\mathrm{n}^{\circ}$ 9.249/95, suspendeu o mecanismo de correção monetária das Demonstrações Contábeis, extinguindo, inclusive, a Unidade Fiscal de Referência (UFIR), que servia como indexador monetário. Com isso, não foi mais possível reconhecer contabilmente os efeitos inflacionários para efeitos societários e tributários. Em 22 de março de 2001, o CFC emitiu a Resolução $n^{\circ}$ 900, na qual estabelece que a aplicação do princípio da atualização monetária é compulsória quando a inflação acumulada no triênio, com base no IGP-M, for de $100 \%$ ou mais.

Portanto, a passagem histórica retratada elucida as transformações envolvidas no processo que envolve a denominada dialética da complementaridade. Nela, as normas passam 
a sofrer alterações pela superveniência de mudanças (no plano dos fatos e valores), diante da tensão existente entre o evento econômico (fato) a ser reconhecido, mensurado e divulgado e o que se deseja (valor objetivado), podendo até tornar-se necessária sua revogação.

\section{A PROPOSTA de ANÁlISE dA REGULAÇÃo CONTÁBIL À LUZ DA TEORIA REALEANA}

A presente seção é dedicada ao ensaio propriamente dito. Inicialmente, são analisados os constructos da Teoria Tridimensional do Direito. Na sequiência, são apresentadas as contribuições da Teoria Realeana à compreensão da regulação contábil.

\subsection{Os constructos da Teoria Realeana aplicados à Regulação Contábil}

A principal crítica a qual estudos interdisciplinares ficam vulneráveis diz respeito à compatibilização dos signos e significados (termos e conceitos) entre as diferentes disciplinas. Portanto, o Quadro 1 apresenta uma proposta de conciliação entre a Teoria Tridimensional do Direito e a Contabilidade.

\begin{tabular}{|c|c|}
\hline Conceito Jurídico & Conceito Contábil \\
\hline $\begin{array}{l}\text { Fato jurídico } \\
\text { O conceito de fato surge } \\
\text { como momento de um } \\
\text { processo, um elo de } \\
\text { encadeamento dos atos } \\
\text { humanos, quer em função } \\
\text { de atos anteriores, quer em } \\
\text { razão da natureza. O fato é } \\
\text { algo que somente o é } \\
\text { enquanto se situa no } \\
\text { envolver da história, } \\
\text { recebendo significado no } \\
\text { contexto ou na estrutura } \\
\text { em que ele ocorre } \\
\text { (REALE, 2005, p. 95). }\end{array}$ & $\begin{array}{l}\text { Fato (ou ato) contábil } \\
\text { É qualquer ocorrência que modifique o patrimônio, seja decorrente de negócio } \\
\text { realizado pela administração (ato) ou não (fato). A expressão fatos contábeis é } \\
\text { mais abrangente, pois inclui os fatos administrativos (ou fato de gestão, é } \\
\text { qualquer negócio realizado pela administração que modifique o patrimônio da } \\
\text { empresa, em termos de qualidade ou quantidade). } \\
\text { "Os atos praticados pelos administradores ou donos da empresa, que afetam o } \\
\text { patrimônio empresarial são denominados fatos administrativos ou contábeis" } \\
\text { (PADOVEZE, 2004). } \\
\text { "São os eventos (de natureza econômica, em sua maioria) que provocam } \\
\text { alterações, e que são registrados pela contabilidade em função de uma } \\
\text { planificação anterior" (IUDÍCIBUS et al., 1983, p.99). } \\
\text { "São ocorrências que se registram no patrimônio, trazendo-lhe variações } \\
\text { específicas ou quantitativas. São todos os acontecimentos suscetíveis de registro, } \\
\text { ou contabilização, donde a designação de contábeis" (FRANCO, 1997, p. 58). } \\
\text { "Transações realizadas pela entidade e os demais eventos que afetam seu } \\
\text { patrimônio" (SZUSTER et al., 2008, p. 47). }\end{array}$ \\
\hline $\begin{array}{l}\text { Norma Jurídica } \\
\text { É considerada a forma que } \\
\text { o jurista (tanto o legislador } \\
\text { quanto o juiz de direito) } \\
\text { usa para expressar o que } \\
\text { deve ou não deve ser feito } \\
\text { para a realização de um } \\
\text { valor ou impedir a } \\
\text { ocorrência de um } \\
\text { desvalor, integrando algo } \\
\text { da realidade social numa } \\
\text { estrutura regulativa } \\
\text { obrigatória (REALE, } \\
\text { 2005, p. 125). }\end{array}$ & $\begin{array}{l}\text { Norma contábil } \\
\text { É regra complementar obediente aos princípios fundamentais (ou à Estrutura } \\
\text { Conceitual Básica), considerada necessária como padrão de conduta para o } \\
\text { registro de fatos e elaboração de demonstrações e informações contábeis. } \\
\text { "São convencionais e não fundamentais para o registro de fatos e elaboração das } \\
\text { demonstrações e informações contábeis, devendo ser interpretadas como regras } \\
\text { complementares, obedientes aos princípios fundamentais, e necessárias como } \\
\text { padrões de conduta ou guias-de-orientação para o exercício profissional" } \\
\text { (FRANCO, 1997, p. 208). } \\
\text { "São diretivas de natureza operacional. Alicerçadas nos princípios e a eles } \\
\text { subordinadas, são comandos que determinam o que deve ser feito. São critérios, } \\
\text { métodos, procedimentos ou técnicas. Norma é uma indicação de conduta } \\
\text { obrigatória" (NIYAMA et al., 2001, p. 315). }\end{array}$ \\
\hline
\end{tabular}

Quadro 1 - Similaridades e aplicação da Teoria Tridimensional na Contabilidade

Fonte: elaboração própria. 
No Quadro 1, a similaridade verificada entre o conceito de fato jurídico e de fato ou ato contábil consiste no significado que passa algo a ter dentro de um contexto ou estrutura, mais especificamente econômico e administrativo. O fato como modificação patrimonial surge de um processo que decorre, essencialmente, de atos humanos e que é suscetível de avaliação.

A semelhança aplicável à norma jurídica e contábil se refere à indicação ou padrão de conduta, devidamente expressa, como forma de integrar algo da realidade social (evento econômico) numa estrutura (Demonstrações Contábeis).

O valor, importante componente do modelo proposto por Reale (2005), é definido como elemento de mediação dialética entre fato e norma, sendo ele mesmo a expressão de um desenvolvimento histórico no plano das estimativas. De acordo com Reale (1977, p. 171), “o problema dos valores não pode ser colocado fora da história, pois é nela que se manifestam e adquirem sentido, como sínteses constantes das decisões humanas (dever ser) sobre o real". Segundo Birou (1976, p. 419), o valor corresponde à "capacidade que um objeto (coisa, idéia ou outra pessoa) tem de satisfazer um desejo, uma necessidade ou uma aspiração humana".

O conceito de valor é investigado e conceituado em diferentes áreas do conhecimento. É possível conceber que o valor exprime uma relação entre as necessidades e aspirações do homem e a capacidade das coisas, objetos ou serviços, em as satisfazer e que desta relação se percebe a existência de uma hierarquia de valores, segundo a importância ou a prioridade das necessidades e a capacidade dos mesmos para as satisfazerem.

Rokeach (1973, p.20) sugere que "os valores são representações cognitivas e transformações das necessidades". Para Kluckholm apud Ros (2001), valores correspondem a uma concepção explícita ou implícita própria de um indivíduo ou característica de um grupo, sobre o que é desejável e que influencia a seleção de modos de conduta, meios e fins de ações acessíveis. Inglehart (1990), ao afirmar que os valores decorrem mais do processo de socialização do que um resultado estrito das condições de escassez vividas pelo homem. Reale (1996b, p. 8) afirma que o valor "age como conteúdo ou como ingrediente essencial da realidade estudada".

Segundo Hessen (1980), os valores podem ser classificados em:

a) valores sensíveis (os valores do agradável e do prazer; os valores vitais ou da vida e os valores de utilidade que coincidem com os chamados valores econômicos);

b) valores espirituais (os valores lógicos, os valores ético ou do bem moral, os valores estéticos, ou do belo e os valores religiosos ou do "sagrado").

Supõe esta teoria que não há coisa alguma que não tenha um valor. É possível, então, perceber que os elementos de que se compõe o mundo não são indiferentes, ou seja, não há coisa alguma diante da qual não se adote uma posição de preferência, positiva ou negativa, boas ou más, úteis ou prejudiciais; porém nenhuma absolutamente indiferente. Como afirma Morente (1980, p. 299):

Poderíamos acrescentar que os valores se descobrem. Descobrem-se como se descobrem as verdades científicas. Durante certo tempo o valor não é conhecido como tal valor, até que chega na história um homem ou um grupo de homens que de repente têm a possibilidade de intuí-lo, e então o descobre.

Ainda, segundo Morente, os valores não são nem coisas nem impressões subjetivas, eles apenas valem, ou seja, quando se diz de algo que vale, não se diz nada do seu ser, mas que não é indiferente. A não-indiferença é a essência do valer. Nesse sentido, Morente (1980) aponta quatro categorias na esfera do valor: 
a) valer - a não-indiferença constitui o valer. A coisa que vale é algo que tem valor;

b) qualidade - se eu separo a beleza daquilo que é belo, a beleza carece de ser. A beleza não é; beleza é qualidade de uma coisa;

c) polaridade - a não-indiferença implica sempre um ponto de indiferença e que se afasta mais ou menos desse ponto de indiferença. No caso, o afastamento do zero pode ser positivo ou negativo;

d) hierarquia - diante da multiplicidade de valores existe uma hierarquia que é classificada de acordo com a maior ou menor distância do ponto de indiferença (ponto zero).

Toda ação humana consciente tem por objetivo alcançar determinados fins e esses são escolhidos pelo homem de acordo com os valores que ele considera importantes para a sua vida. Portanto, são ingredientes do processo cultural, inseparáveis da vida cotidiana, cujas regras de conduta pressupõem um processo político, um envolvimento com negociações, barganhas, permutas e, até, a utilização de força, as quais possivelmente estão impregnadas de valor (REALE, 2005).

Considerando, então, que os valores estão necessariamente aderidos às coisas e que estão integrados à realidade, a teoria dos valores ou axiologia constitui um fundamento para o esclarecimento e a análise de eventos econômicos, suscetíveis aos conceitos de utilidade, que devem ser avaliados antes de começarem, propriamente, as discussões que envolvem a regulação desses fenômenos.

Como exemplo para ilustrar a inter-relação dos conceitos do direito com os contábeis, é citado o pronunciamento técnico CPC $\mathrm{n}^{\circ} 13$ que trata da adoção das Leis $\mathrm{n}^{\circ} 11.638 / 07$ e 11.941/09, no que tange à contabilização do arrendamento mercantil financeiro. Com a adoção dos padrões internacionais de contabilidade prevalece o registro, no ativo imobilizado, dos direitos decorrentes de operações que transfiram à entidade os benefícios, os riscos e o controle desses bens.

Ao considerar a prevalência da essência sobre a forma para justificar o reconhecimento de um ativo contábil, verifica-se um valor como elemento de mediação dialética entre o fato e a norma, havendo, portanto, uma nova integração normativa (pronunciamento do CPC) de fatos (arrendamento mercantil) segundo valores (essência sobre a forma).

\subsection{Contribuições da teoria tridimensional para a análise do fenômeno da regulação da contabilidade}

Inicialmente é analisada a validade do processo regulatório da contabilidade, conforme proposto por Miguel Reale. Na seqüência, o processo dialético entre fato-valor-norma é analisado no que tange à norma contábil. Finalmente, a análise é ampliada mediante a inserção de outros conceitos, construindo-se assim, dedutivamente, uma crítica geral.

a) Análise da validade do processo regulatório contábil

Diante das transformações econômicas, políticas, sociais e tecnológicas nas últimas décadas, têm sido questionadas a validade e a adequação das rígidas estruturas normativas e concepções contábeis, principalmente ao serem consideradas as atuais necessidades dos usuários das informações contábeis, e, consequientemente, a própria qualidade da informação que envolve o processo decisório. 
De acordo com Reale (1994, p. 14), "um conjunto de determinados pressupostos de validade precisa ser obedecido para a devida produção de prescrições normativas". A inserção de novos elementos (vigência, eficácia e fundamento), capazes de identificar a validade da norma na análise da regulação da contabilidade, pode contribuir para a elucidação de questões importantes como: o distanciamento entre prática contábil e os ditames dos padrões contábeis (norma contábil); a legalidade que reveste os atos normativos; e a valoração dos mandamentos nucleares que alicerçam a estrutura de regulação da contabilidade.

No Quadro 2 apresentam-se elementos da validade da norma, sendo que o teor jurídico está fundamentado em Reale (2005) e a analogia à contabilidade uma proposição dos autores.

\begin{tabular}{|c|l|l|}
\hline Elementos & \multicolumn{1}{|c|}{ Teor Jurídico (Reale, 2005) } & \multicolumn{1}{|c|}{ Analogia à Contabilidade } \\
\hline Vigência & $\begin{array}{l}\text { Diz respeito à competência dos órgãos e aos } \\
\text { processos de reconhecimento e produção do } \\
\text { direito no plano normativo. }\end{array}$ & $\begin{array}{l}\text { Corresponderia à competência dos entes } \\
\text { reguladores e ao alcance das normas } \\
\text { emitidas, por exemplo, CVM, CFC e CPC. }\end{array}$ \\
\hline Eficácia & $\begin{array}{l}\text { Corresponde à regra jurídica enquanto momento } \\
\text { da conduta humana, ou seja, o direito autêntico } \\
\text { não é apenas declarado, mas reconhecido e e } \\
\text { vivido pela sociedade. }\end{array}$ & $\begin{array}{l}\text { Corresponderia à efetiva aplicação dos } \\
\text { dispositivos de regulação (política contábil) } \\
\text { aos fatos. } \\
\text { Seria o reconhecimento da previsão } \\
\text { normativa pelos entes regulados através da } \\
\text { efetiva conduta (prática contábil). }\end{array}$ \\
\hline Fundamento & $\begin{array}{l}\text { Compreende o valor ou fim almejado pela regra } \\
\text { do direito. Não é possível estabelecer uma regra } \\
\text { jurídica desvinculada da finalidade que legitima } \\
\text { sua eficácia e vigência. }\end{array}$ & $\begin{array}{l}\text { Corresponderiam aos valores que } \\
\text { fundamentam a construção dos princípios } \\
\text { fundamentais e das qualidades essenciais } \\
\text { da informação. }\end{array}$ \\
\hline
\end{tabular}

\section{Quadro 2 - Elementos da validade da norma}

Fonte: elaboração própria.

O Quadro 2 apresenta pontos de semelhança entre os conceitos jurídicos, dos elementos considerados capazes de validar a norma (vigência, eficácia e fundamento); e os aspectos contábeis que envolvem a emissão de normas de contabilidade, as práticas contábeis adotadas pelos entes regulados e a essência dos princípios fundamentais que alicerçam a estrutura da contabilidade.

Larrimbe, Barsantini e Vázquez (1992, p. 6-7) afirmam que normas contábeis profissionais são emitidas por órgãos profissionais da contabilidade e normas contábeis legais são constituídas por leis, decretos, instruções, resoluções, entre outras. Segundo Bonavides (2002, p. 111-112), enquanto "a legalidade nos sistemas políticos exprime basicamente a observância das leis", a legitimidade "levanta o problema de fundo, questionando acerca da justificação e dos valores do poder legal". Essa dicotomia pode trazer alguns entraves à boa prática contábil, uma vez que os objetivos podem ser antagônicos.

Analisando a questão sob o prisma da validade da contabilidade, à luz da teoria tridimensional do direito, os aspectos relativos à vigência da norma, de sua eficácia e dos fundamentos que a legitimam podem elucidar o papel que estas normas desempenham no campo prático, como também em relação aos eventuais conflitos que envolvem aspirações e interesses distintos.

b) Percepção do processo dialético que envolve os elementos (norma, fato e valor) presentes no ambiente de regulação

O caráter concreto e dinâmico da tridimensionalidade realeana, no qual fato, valor e norma estão sempre presentes e correlacionados em qualquer expressão da vida humana, possibilita olhar a contabilidade como uma extensão desta dimensão, revelando a 
dialeticidade que envolve esses três elementos no campo contábil. Tal perspectiva, de certa forma, amplia a discussão em torno dos diversos enfoques que podem ser adotados na orientação de pesquisas e solução de problemas contábeis. Uma vez presentes e relacionados esses três elementos em qualquer expressão da experiência contábil, as questões éticas, legais, fiscais, institucionais, sociais, históricas e/ou estruturais poderiam ser observadas como faces de um mesmo paradigma, o tridimensional.

Nesse novo olhar, ao reconhecer que os eventos econômicos são integrados normativamente segundo valores, é possível evitar o isolamento desses fatores (norma, fato e valor) no processo de regulação. Correlacionando-os dialeticamente, com a possibilidade de "prever-se, embora de maneira conjetural, como eles poderão influir reciprocamente, inclusive, em função da superveniência de novas mutações factuais, axiológicas e normativas" (REALE, 2005, p. 152). Não cabe, portanto, apenas a uma determinada perspectiva unilateral compreender o fenômeno da regulação da contabilidade.

c) Ampliação da perspectiva de análise do processo de regulação contábil pela inserção de novos conceitos

O fornecimento de informações consideradas úteis para os diversos usuários se constitui no objetivo essencial da contabilidade. $O$ atributo da utilidade da informação contábil, como valor ideal, é objetivado por meio de normas emitidas por órgão regulador e está presente nas características qualitativas da informação contábil (confiabilidade, tempestividade, comparabilidade e compreensibilidade), segundo a Resolução CFC $\mathrm{n}^{\circ}$ 785/95; ou compreensibilidade, relevância, confiabilidade e comparabilidade, segundo o Pronunciamento CPC-00. Da mesma forma, são consagrados princípios fundamentais da contabilidade baseados em valores, que juntamente com os atributos daquelas características qualitativas, são capazes de dar legitimidade às normas complementares que integram o processo contábil.

Segundo Szuster et al. (2008, p. 33-35), tal processo (ciclo contábil) é composto por cinco fases: captação dos dados sobre os atos e os fatos que afetam o patrimônio da entidade; o reconhecimento contábil, que envolve a definição do momento de reconhecimento, a classificação dentre as diversas contas contábeis e a mensuração do montante que afetou o patrimônio da entidade; a acumulação dos registros nas bases de dados; a sumarização dos diversos dados registrados; e a evidenciação das demonstrações contábeis e demais relatórios contábeis.

As Demonstrações Contábeis (mundo contábil) são formadas por contínuas intenções de valor que atuam sobre eventos e transações essencialmente econômicos (relação fatovalor), numa relação dinâmica e complementar, e que se reflete em várias direções normativas, como, por exemplo, na convergência aos padrões internacionais. Conseqüentemente, estas proposições normativas são convertidas em normas contábeis em virtude da interferência de poder, ou seja, de quem define a oportunidade e a conveniência da norma ser consagrada (ente dotado de poder normativo). Vale destacar que as mesmas normas contábeis podem sofrer alterações de sentido em decorrência das mudanças no plano dos fatos e valores, situados no tempo e no espaço, e com isso uma retomada de posição ocorre, por meio de alterações normativas, perante a nova relação fato-valor surgida.

A presença dos três elementos (fato, valor e norma), no curso da regulação da contabilidade, estabelece uma importante correlação funcional: a validade do processo normativo. Para a análise da validade da norma é necessário levar em consideração os aspectos formais que envolvem a competência; o reconhecimento e a produção da norma (vigência); a sua efetiva correspondência com a realidade vivida pela sociedade (eficácia); e o 
reconhecimento dos valores que fundamentam a construção dessas regras e que estão inseridos na estrutura conceitual básica da contabilidade e nos princípios fundamentais de contabilidade (legitimidade ou fundamento).

As divergências eventualmente identificadas entre as prescrições normativas e a prática contábil adotada pelos entes regulados podem ser analisadas pela perspectiva da validade do processo normativo. Por último, mas não menos importante, seria legítimo lembrar que, embora a regulação, ampliada sua visualização pela teoria tridimensional de Miguel Reale, seja a exteriorização final do processo fato-valor-norma, existe um "substratum" conceitual anterior que deve ser considerado, constituído pelo pensamento dos teóricos da contabilidade, muitas vezes alheio à praticidade regulatória, mas rico em idéias e filosofias.

A Figura 4 representa de forma abrangente e sistêmica o processo normativo à luz da teoria tridimensional. Cuja contribuição para o aperfeiçoamento da regulação contábil é significativa pela sua abordagem concreta e dinâmica, ou seja, por ser aplicável em qualquer dimensão da experiência contábil e por reconhecer que as mudanças que ocorrem no plano das normas, dos fatos e valores se desenvolvem e se inter-relacionam no tempo.

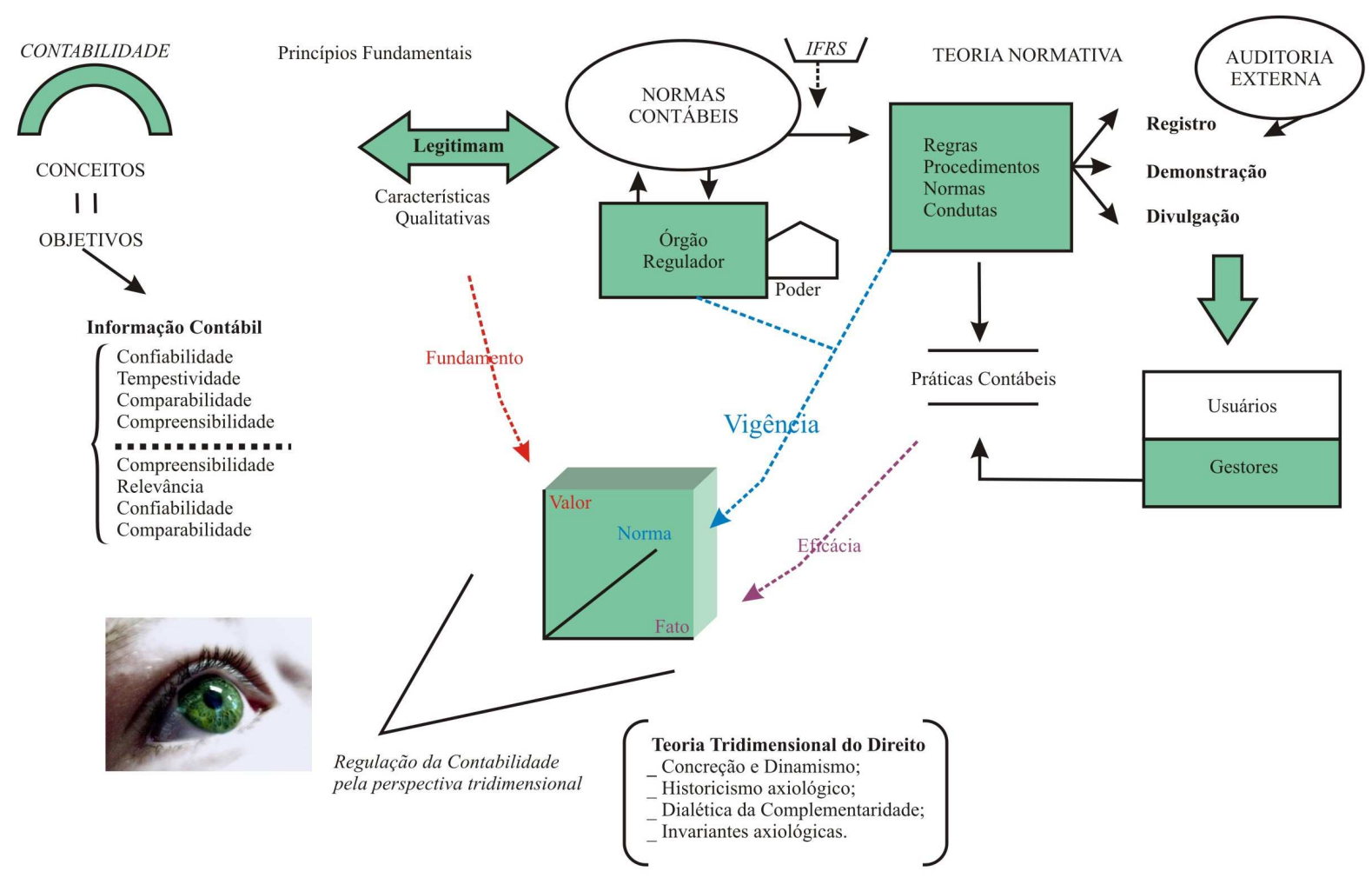

Figura 4 -Visão geral da regulação da contabilidade à luz da abordagem interdisciplinar Fonte: elaboração própria.

Para exemplificar a análise da validade da norma e o processo dialético que envolve os elementos (norma, fato e valor) e os aspectos históricos e culturais, é apresentada uma situação hipotética. Até 2007 havia uma norma, criada em 1935, que disciplinava o seguinte: a receita de vendas deve ser reconhecida a partir do momento que houver intenção de compra manifestada publicamente. Em 2008, o momento do reconhecimento, passou a ser a partir do momento que o aumento do ativo (ou redução do passivo) possa ser determinado em bases confiáveis e tenha um grau suficiente de certeza. O Quadro 3 sumariza a análise: 


\begin{tabular}{|l|l|}
\hline \multicolumn{1}{|c|}{ 1935 - 2007 } & \multicolumn{1}{c|}{ em 2008 } \\
\hline $\begin{array}{l}\text { Objetivo da norma: registrar e divulgar a receita de } \\
\text { vendas com base apenas no interesse manifestado } \\
\text { publicamente. }\end{array}$ & $\begin{array}{l}\text { Objetivo da norma: reconhecer a receita de vendas a } \\
\text { partir de bases confiáveis. }\end{array}$ \\
\hline $\begin{array}{l}\text { Aspecto cultural (1935): As relações comerciais são } \\
\text { "garantidas" para reputação (honra). }\end{array}$ & $\begin{array}{l}\text { Aspecto cultural: as relações comerciais são } \\
\text { garantidas por instrumentos contratuais, com forte } \\
\text { interferência do poder público. Individualidade. }\end{array}$ \\
\hline $\begin{array}{l}\text { Aspecto histórico (1935): Economia fechada, intensa } \\
\text { recorrência entre poucos agentes }\end{array}$ & $\begin{array}{l}\text { Aspecto histórico: internacionalização da economia, } \\
\text { globalização dos negócios e elevada competitividade. }\end{array}$ \\
\hline $\begin{array}{l}\text { Valor objetivado na norma: honra. } \\
\text { Valores objetivados na norma: utilidade e confiança. }\end{array}$ \\
\hline $\begin{array}{l}\text { Pelo normativismo (positivismo): apenas pelo } \\
\text { aspecto da vigência, a norma seria válida. }\end{array}$ & $\begin{array}{l}\text { Pelo normativismo (positivismo): apenas pelo } \\
\text { aspecto da vigência, a norma seria válida. }\end{array}$ \\
\hline $\begin{array}{l}\text { Pela perspectiva tridimensional: hoje a norma não } \\
\text { seria válida, apesar de atendidas as exigências } \\
\text { formais/legais (vigência), a norma não produz efeitos } \\
\text { práticos (eficácia) e o valor presente na norma (honra) } \\
\text { não seria reconhecida como essencial (fundamento } \\
\text { ou legitimidade). }\end{array}$ & $\begin{array}{l}\text { Pela Perspectiva tridimensional: a norma seria } \\
\text { válida, pois são atendidas as exigências formais/legais } \\
\text { (vigência), a norma produz efeitos práticos (eficácia) } \\
\text { e o valor presente na norma (confiança) seria } \\
\text { reconhecida como essencial (fundamento ou } \\
\text { legitimidade). }\end{array}$ \\
\hline
\end{tabular}

Quadro 3 - Análise da validade da norma e do processo dialético

Fonte: elaboração própria.

\section{CONSIDERAÇÕES FINAIS}

Entendendo-se a Contabilidade como uma instituição social, cujo fim compreende a redução da assimetria informacional, o delineamento de incentivos e a estruturação e sinalização de mecanismos de avaliação de desempenho, foi analisada neste ensaio a teoria da regulação pela perspectiva Tridimensional do Direito. Segundo essa, a regulação é uma construção social, portanto, permeada de valores e estabelecida por uma instituição dotada de poder, sendo, assim vinculada à democratização do processo contábil na medida em que os diferentes atores da sociedade, além dos responsáveis pelo registro e normatização, estão presentes nestas perspectivas. Dessa forma, a Contabilidade deixa de ser apenas um meio, um instrumento, um mecanismo, para aproximar-se da almejada modernidade, contribuindo para a emancipação do homem, ente histórico-cultural e fonte de todos os valores.

Nesse sentido, Iudícibus (2007b, p. 6) menciona que:

ao adotarmos as normas internacionais, daremos um passo à frente. Seremos comparáveis, mas não poderemos ser, nunca, "incomparáveis", no que se refere à qualidade, se, livres de grilhões, tivéssemos a coragem de dar grandes saltos de qualidade em nossa contabilidade, indo à procura do "valor" econômico-subjetivo da empresa, mais que a parâmetros contábeis limitados.

Percebe-se que se adotou uma política de melhoria de nível de evidenciação, eliminando os contras da marginalidade global e seus custos de transações, que por seu turno eram confeccionadas demonstrações de difícil comparabilidade com o resto do mundo (ou parte do mundo). Ao adotar padrões internacionais emanados pelo IASB, busca-se a geração da informação comparável; não quer dizer, ainda, que seja o desejado (a objetividade de nossos padrões fosse substituída, com bom senso, por uma subjetividade responsável, ou seja, pela prevalência sempre que possível da essência econômica à forma jurídica).

O convergir às normas internacionais é um meio de melhoraria dos padrões brasileiros de qualidade, haja vista que não se conseguiu fazê-lo anteriormente, espontaneamente, o que nos leva a uma perda de parte de nossa identidade ou de nossas peculiaridades. Priva-nos, 
nacionalmente, de excelências em alguns momentos, mas, em média, atende-se ao padrão geral e amplo de evidenciação (internacional).

Portanto, os aspectos relativos à vigência da norma, de sua eficácia e dos fundamentos que a legitimam podem ajudar a explicar o papel da regulação e seu desempenho no campo prático. Podem constituir-se em uma oportunidade de pesquisa sobre a aceitação e praticabilidade das normas no dia-a-dia dos profissionais, considerando-se que haja conflitos que envolvem aspirações e interesses distintos dos órgãos reguladores e entre si, e também com os regulados. A perspectiva tridimensional poderia ser um meio de se fazer as análises dos diversos enfoques possíveis aos conflitos e problemas de regulação contábil, através da interligação entre Valor-Fato-Norma ou sua Nomogênese, que poderia demonstrar ao regulador a percepção pelos regulados da nova norma e de como essa seria ou não aceita por todos. O processo de democratização por meio de audiências públicas poderia ser analisado e mensurado quanto à sua efetividade e seus resultados.

A Figura 4 apresenta uma visão geral da perspectiva tridimensional para a compreensão do fenômeno da regulação contábil, tendo como ponto de partida a objetivação de valores da informação contábil (confiabilidade, relevância, tempestividade), como tentativa de atender às expectativas dos múltiplos usuários. Da mesma forma, valores também estão presentes nos princípios fundamentais que irão definir os pilares da estrutura contábil. A interferência de poder, que definirá a oportunidade e conveniência da norma, está presente nos órgãos reguladores. A questão que envolve a validade dessas normas emanadas compreende a identificação e análise de aspectos formais relacionados, principalmente, às exigências legais (vigência), do reconhecimento da utilidade prática (eficácia) e da aceitação dos valores escolhidos e presentes nas normas (legitimidade).

Para concluir, é esperada, a partir dessa perspectiva, a ampliação do entendimento do atual movimento regulatório pelo qual passa a contabilidade societária brasileira, o que envolveu duas alterações consecutivas na Lei $\mathrm{n}^{\circ}$ 6.404/76, (Leis $\mathrm{n}^{\circ}$ 11.638/07 e 11.941/09); além da criação do CPC e a recente edição de uma série de deliberações por parte da CVM. A opção por uma abordagem ainda não explorada na literatura contábil pode ensejar limites, entretanto há expectativa que os argumentos teóricos aqui apresentados sirvam como fonte de inspiração para que outros pesquisadores identifiquem hipóteses de pesquisas a serem testadas empiricamente.

\section{REFERÊNCIAS}

ABRANCHES, S. Reforma regulatória: conceitos, experiências e recomendações. Revista do Serviço Público, v. 50, n. 2, p. 19-49, abr./jun. 1999.

ANDRADE, Rosamaria Calaes de. Interdisciplinaridade: um novo paradigma curricular. A educação na perspectiva construtivista: reflexões de uma equipe interdisciplinar. Petrópolis: Vozes, 1998.

BALDWIN, R.; CAVE, M. Understanding regulation: theory, strategy, and practice. Oxford: Oxford University Press, 1999.

BECKER, Gary S. A theory of competition among pressure groups for political influence. Quarterly Journal of Economics, n. 98, p. 371-400, August, 1983.

BELKAOUI, Ahmed Riahi. Accounting theory. 5 ed. Londres: Business Press, Thomson Learning, 2004.

BIROU, A. Dicionário das ciências sociais. 2. ed. Lisboa: Publicações Dom Quixote, 1976. 
BOHR, Niels. Física atômica e conhecimento humano. Ensaios: 1932-1957. Rio de Janeiro: Contraponto, 2000.

BRASIL. Agência Nacional de Energia Elétrica. Despacho no 4.796, de 24 de dezembro de 2008. Diário Oficial da União, DF, 26 dez. 2008.

Comissão de Valores Mobiliários. Deliberação no 25, de 16 de dezembro de 1985.

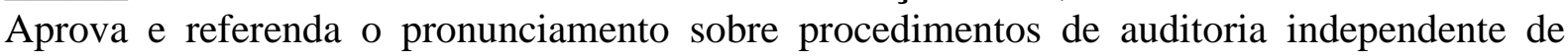
instituições financeiras e entidades equiparadas, permitido pelo Instituto Brasileiro de Contadores. Diário Oficial da União, DF, 16 dez. 1985.

Comissão de Valores Mobiliários. Deliberação no 29, de 5 de fevereiro de 1986. Aprova e referenda o pronunciamento do IBRACON sobre a Estrutura Conceitual Básica da Contabilidade. Diário Oficial da União, DF, 13 fev. 1986.

Comissão de Valores Mobiliários. Deliberação no 506, de 19 de junho de 2006. Aprova o Pronunciamento do IBRACON sobre Práticas Contábeis, Mudanças nas Estimativas Contábeis e Correção de Erros. Diário Oficial da União, DF, 20 jun. 2006.

Comissão de Valores Mobiliários. Deliberação no 539, de 14 de março de 2008. Aprova o Pronunciamento Conceitual Básico do CPC que dispõe sobre a Estrutura Conceitual para a Elaboração e Apresentação das Demonstrações Contábeis. Diário Oficial da União, DF, 14 mar. 2008.

Comitê de Pronunciamentos Contábeis. Estrutura conceitual básica: estrutura conceitual para a elaboração e apresentação das demonstrações contábeis, 14 mar. 2008.

Conselho Federal de Contabilidade. Resolução CFC n⿳0 785, de 28 de julho de 1995. Aprova a NBC T 1 - Das Características da Informação Contábil. Diário Oficial da União, Poder Executivo, Brasília, DF, 1 out. 1995.

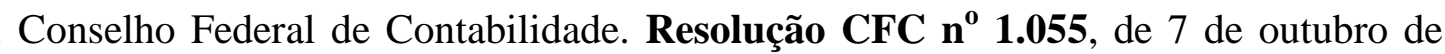
2005. Cria o Comitê de Pronunciamentos Contábeis. Diário Oficial da União, Poder Executivo, Brasília, DF, 24 de out. 2005.

Conselho Federal de Contabilidade. Resolução CFC no 1.121, de 28 de março de 2008. Aprova a NBC T 1 - Estrutura Conceitual para a Elaboração e Apresentação das Demonstrações Contábeis. Diário Oficial da União, Poder Executivo, Brasília, DF, 01 de abr. 2008.

Congresso Nacional. Lei $\mathbf{n}^{\mathbf{0}}$ 11.638, de 27 de dezembro de 2007. Altera e revoga dispositivos da Lei $\mathrm{n}^{\mathrm{o}}$ 6.404, de 15 de dezembro de 1976, e da Lei $\mathrm{n}^{\circ}$ 6.385, de 7 de dezembro de 1976, e estende às sociedades de grande porte disposições relativas à elaboração e divulgação de demonstrações financeiras. Diário Oficial da União, Poder Executivo, Brasília, DF, 28 de dez. 2007, edição extra.

. Congresso Nacional. Lei $\mathbf{n}^{\mathbf{0}} \mathbf{1 1 . 9 4 1}$, de 27 de maio de 2009. Altera a legislação tributária federal relativa ao parcelamento ordinário de débitos tributários, concede remissão nos casos em que especifica, institui regime tributário de transição, e dá outras providências. Diário Oficial da União, Poder Executivo, Brasília, DF, 28 de maio 2009.

. Superintendência de Seguros Privados. Circular no 379, de 19 de dezembro de 2008. Dispõe sobre alterações das Normas Contábeis a serem observadas pelas sociedades seguradoras, resseguradoras, sociedades de capitalização e entidades abertas de previdência complementar, instituídas pela Resolução CNSP $n^{\circ}$ 86, de 3 de setembro de 2002. Diário Oficial da União, DF, 23 dez. 2008. 
BONAVIDES, Paulo. Ciência política. 10 ed. São Paulo: Malheiros Editores. 2001.

BRAY,F. Sewell. Accounting postulates and principles. In: BACKER, Morton. Modern accounting theory. New Jersey: Prentice - Hall, 1966. cap. 2, p. 28-47.

CANOTILHO, José Joaquim Gomes. Curso de Direito Constitucional, 25.ed. São Paulo: Saraiva, 1999.

CARDOSO, Ricardo Lopes. Reflexos da regulação econômica na informação contábil prestada pelo ente regulado. In: PECI, A. (org.). Regulação no Brasil. São Paulo: Atlas, 2007. p. 147-178.

CHANTIRI, Rouba. Les recherches anglo-saxonnes sur la régulation comptable. In: Association Française de Comptabilité, 1995, Montpellier. Actes du XVIème Congrès. Université de Montpellier, 1995. p. 469-486.

DIAS FILHO, José Maria; MACHADO, Luiz Henrique B. Abordagens da pesquisa em contabilidade. In: IUDÍCIBUS, S.D.; LOPES, A.B. (orgs.). Teoria avançada da contabilidade. São Paulo: Atlas, 2004. p. 15-69.

FRANCO, Hilário. Contabilidade geral. São Paulo: Atlas, 1997.

A contabilidade na era da globalização: temas discutidos no XV Congresso Mundial de Contadores, Paris, de 26 a 29-10-1997. São Paulo: Atlas, 1999.

FOROUGHI, Tahirih; REED, Barbara. A survey of the present and desirable international Journal of Accounting Education and research. The International Journal of Accounting Education and research. Urbana v. 23, n. 1, p. 69-82, Fall 1987.

GARCÍA, Angeles Mateos. A teoria dos valores de Miguel Reale. São Paulo: Saraiva, 1999.

HENDRIKSEN, Eldon S.; BREDA, Michael F. Van. Teoria da contabilidade. São Paulo: Atlas, 1999.

HOPWOOD, Anthony G. Whither Accounting research? The Accounting Review, v. 82, n. 5, p. 1365-1374, 2007. doi:10.2308/accr.2007.82.5.1365

INGLEHART, R. Culture shift in advanced industrial society. New Jersey: Princeton University Press, 1990.

IUDÍCIBUS, Sérgio. Teoria da contabilidade. 8 ed. São Paulo: Atlas, 2007a. 6, 2007b.

Contabilidade: entre umas e outras. Revista de Informação Contábil, v. 1, n. 1, p.1-

; MARTINS, Eliseu; GELBCKE, Ernesto R. Manual de contabilidade das sociedades por ações: aplicável às demais sociedades. 7 ed. São Paulo: Atlas, 2007.

; RAMOS, Alkindar de Toledo; KANITZ, Stephen Charles; MARTINS, Eliseu; WEBER FILHO, Eduardo; DOMINGUES JÚNIOR, Ramon; CASTILHO, Edison; BENATTI, Luiz. Contabilidade introdutória. 6 ed. São Paulo: Atlas, 1983.

JAPIASSU, H; MARCONDES, D. Dicionário básico de filosofia. Rio de Janeiro: Zahar, 2001.

KING, Thomas A. More than a numbers game: a brief history of accounting. New Jersey: Willey, 2006.

KUHN, T. The structure of scientific revolutions. Chicago: University of Chicago Press, 1970. 
LARRIMBE, Miguel; BARSANTINI, Jorge; VÁZQUEZ, Alicia Seijas. Las normas contables en el Uruguay. Montevideo: Fundación de Cultura Universitária, 1992.

LAUGHLIN, Richard. Critical reflections on research approaches, accounting regulation and the regulation of accounting. The British Accounting Review, n. 39, p.271-289, 2007. doi:10.1016/j.bar.2007.08.004

LOPES, Alexsandro Broedel; LIMA, Iran Siqueira. Perspectiva para a pesquisa em contabilidade: o impacto dos derivativos. Revista de Contabilidade \& Finanças, v. 15, n. 26, p. 25-41, maio/ago. 2001.

MARTINS, Eliseu. Normativismo e/ou positivismo em Contabilidade: qual o futuro? Revista Contabilidade e Finanças, n. 39, p. 3, set./dez. 2005.

MATTESSICH, Richard. Conditional-normative accounting methodology: incorporating value judgments and mean-end relations of an applied science. Accounting Organizations and Society, v. 20, n. 4, p.259-284, 1995. doi:10.1016/0361-3682(94)00023-O

MORENTE, Manuel Gracia. Lições preliminares de filosofia. São Paulo: Mestre Jou, 1980.

MORIN, Edgar. Ciência com consciência. Rio de Janeiro: Bertrand, 2003.

NIYAMA, J. K., SILVA, César Augusto Tiburcio; PISCITELLI, Roberto Bocaccio. Exame de suficiência em contabilidade. São Paulo: Atlas, 2001.

PADOVEZE, L. C. Manual de contabilidade básica: uma introdução à prática contábil. São Paulo: Atlas, 2004.

POSNER, Richard A. Taxation by regulation. Bell Journal of Economics and Management Science, n. 2, p. 22-50, Spring, 1971.

REALE, Miguel. Pluralismo e Liberdade. São Paulo: Saraiva, 1963.

Experiência e cultura. São Paulo: Grijalbo/Edusp, 1977.

Fontes e modelos do direito. São Paulo: Saraiva, 1994.

Filosofia do direito. São Paulo: Saraiva, 1996a.

Paradigmas da cultura contemporânea. São Paulo: Saraiva, 1996 b.

Teoria tridimensional do direito. São Paulo: Saraiva, 2005.

ROKEACH, M. The nature of human values. New York: Free Press, 1973.

ROS, Maria. Psicologia social de los valores humanos. Madrid: Biblioteca Nueva, 2001.

ROSLENDER, R.; DILLARD, Jesse. Reflections on the interdisciplinary perspectives on accounting research. Critical Perspectives on Accounting, v. 14, n. 3, p.325-351, 2003.

SZUSTER, Natan; CARDOSO, Ricardo Lopes; SZUSTER, Fortunée Rechtman; SZUSTER, Fernanda Rechtman; SZUSTER, Flávia Rechtman.. Contabilidade geral: introdução à contabilidade societária. 2 ed. São Paulo: Atlas, 2008.

VISCUSI, W. K.; VERNON, J. M.; HARRINGTON JR., J. E. Economics of regulation and antitrust. 3 ed. Cambridge, Mass.: The MIT Press, 2000. 